Pena Justisia: Media Komunikasi dan Kajian Hukum
Volume 18, No.1, 2019
Artikel Hasil Penelitian

\title{
PEMBERLAKUAN PEMBATASAN EKSPOR MINYAK BUMI DIKAITKAN DENGAN UNDANG-UNDANG NOMOR 22 TAHUN 2001 TENTANG MINYAK DAN GAS BUMI DAN THE GENERAL AGREEMENT ON TARIFFS AND TRADE 1994 (GATT)/WTO SERTA IMPLIKASINYA TERHADAP KEDAULATAN EKONOMI INDONESIA
}

\begin{tabular}{|c|c|}
\hline \multicolumn{2}{|c|}{$\begin{array}{l}\text { Nasrina }^{* *} \\
\text { ** Fakultas Hukum Universitas Negeri Padjajaran, Indonesia }\end{array}$} \\
\hline Info Artikel & Abstract \\
\hline \multirow[t]{2}{*}{$\begin{array}{l}\text { Keywords: } \\
\text { Petroleum restrictions, } \\
\text { implications, economic sovereignty }\end{array}$} & $\begin{array}{l}\text { The crude oil export restrictions which is necessary to supply domestic needs. However, the } \\
\text { crude oil export restrictions must be applied in accordance with the provisions of the WTO } \\
\text { / GATT that have been ratified and binding on Indonesia to avoid any claim from other } \\
\text { WTO/GATT's member. Indonesia have applied non tariff measures which may restrict } \\
\text { the crude oil export in the form of management and utilization of government's crude oil } \\
\text { entitlement under Joint Cooperation Contract (JOC) by SKKMIGAS and PT. } \\
\text { Pertamina, and contractor's domestic market obligation equal to } 25 \% \text { (twenty five percent) } \\
\text { of contractor's crude oil entitlement under JOC production sharing. This research attempts } \\
\text { to analyze are restrictions non tariff crosses wto to limit oil exports and has implications to } \\
\text { sovereignty indonesian economy Researcher used a descriptive specification analysis, using the } \\
\text { method of juridicial approach normative, that is an approach of the norms of the law, the } \\
\text { comparison of law which emphasized the research through literature or secondary data. The } \\
\text { technique used was literature study practice to a secondary data and retirement conclusions } \\
\text { from the results of studies that have been collected perfomed by using the method of juridical } \\
\text { analysis quantitative. Based on the research, Indonesia apply export restrictions petroleum } \\
\text { by domestic market obligation didn't the violation of the provisions article XI GATT } \\
\text { which are in accordance with article XX General exceptions (g) baving GATT which is } \\
\text { the main objective of natural resource conservation. the government limit in the form of } \\
\text { non tariff of by means of dmo.DMO is interpretation of Sovereignty Indonesian Economy. } \\
\text { Export restrictions petroleum also have an implication to sovereignty economy which is to } \\
\text { change law No. } 22 \text { year } 2001 \text { concerning Oil and natural Gas. Export restrictions } \\
\text { petroleum been written in law no. } 22 \text { 2001 about oil and gas the earth not have an } \\
\text { implication to sovereignty indonesian economy. Indonesia has implement authority and not } \\
\text { the violation of the provisions GATT/WTO }\end{array}$ \\
\hline & Abstrak \\
\hline $\begin{array}{l}\text { Kata kunci: } \\
\text { Pembatasan minyak bumi, } \\
\text { implikasi, kedaulatan ekonomi }\end{array}$ & $\begin{array}{l}\text { Pembatasan ekspor minyak bumi yang perlu dilakukan untuk memenuhi } \\
\text { kebutuhan dalam negeri yang harus sesuai dengan ketentuan WTO/GATT } \\
\text { yang telah diratifikasi dan mengikat Indonesia untuk menghindari adanya } \\
\text { klaim dari negara anggota WTO/GATT lainnya. Indonesia telah } \\
\text { menerapkan ketentuan/kebijakan yang dapat membatasi GAS dan PT } \\
\text { Pertamina dan kewajiban kontraktor menyerahkan minyak bumi bagiannya } \\
\text { menurut KKS bagi hasil sebesar } 25 \% \text { (dua puluh lima persen) (domestic } \\
\text { market obligation). Penelitian ini bertujuan untuk menganalisis apakah } \\
\text { pembatasan non tariff melanggar ketentuan WTO dalam membatasi ekspor } \\
\text { minyak bumi dan memiliki implikasi terhadap kedaulatan ekonomi Indonesia } \\
\text { Penulis menggunakan spesifikasi penelitian berupa deskriptif analitis, dengan }\end{array}$ \\
\hline
\end{tabular}




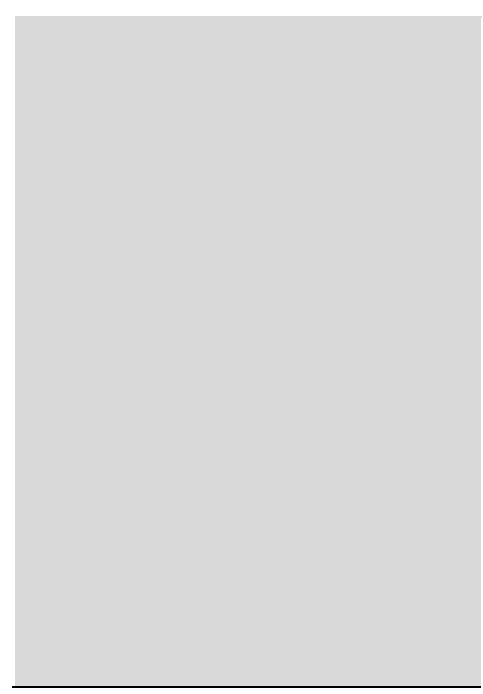

menggunakan metode pendekatan yuridis normatif, yaitu penelitian terhadap asas-asas hukum dan perbandingan hukum yang menitikberatkan kepada penelitian melalui data kepustakaan atau sekunder.Teknik yang digunakan adalah studi lapangan terhadap data sekunder serta penarikan kesimpulan dari hasil penelitian yang sudah terkumpul dengan menggunakan metode analisis yuridis kualitatif. Berdasarkan hasil penelitian, Indonesia menerapkan pembatasan ekspor Minyak bumi dengan tidak melanggar ketentuan Pasal XI GATT yang sudah sesuai dengan pengecualian Pasal XX (g) GATT yaitu memiliki tujuan utama konservasi sumber daya alam. Pemerintah melakukan pembatasan dalam bentuk non tariff dengan cara menerapkan DMO yang merupakan wujud dari kedaulatan ekonomi Indonesia. Pembatasan ekspor minyak bumi yang diatur dalam UU No. 22 Tahun 2001 Tentang Minyak dan Gas bumi tidak memiliki implikasi terhadap kedaulatan ekonomi Indonesia. Indonesia sudah melaksanakan kewenangannya dan tidak melanggar ketentuan GATT/WTO

\section{PENDAHULUAN}

Minyak bumi merupakan sumber daya alam yang sangat penting dan strategis bagi Indonesia.Khususnya sebagai bahan bakar minyak (BBM) untuk memenuhi kebutuhan dalam negeri.Tahun 2010 sekitar 61 juta Kilo Liter yang diperlukan Indonesia untuk memenuhi kebutuhan BBM.Indonesia hanya dapat memproduksi $67 \%$ dari minyak bumi yang diproduksi dalam negeri dan 33\% dari minyak bumi yang di impor. ${ }^{1}$

Minyak bumi yang diproduksi dalam negeri menjadi prioritas utama untuk memenuhi kebutuhan BBM dari hasil produksi minyak bumi nasional yang lebih efisien dan menjamin ketersediaan pasokan melalui Penyelenggaraan kegiatan usaha hulu minyak bumi yang diatur dalam UndangUndang No.22 Tahun 2001. Kenyataannya 5 tahun terakhir Indonesia mengekspor minyak bumi rata-rata 30\% dari produksi minyak bumi dalam negeri dan dari pihak lain. Indonesia harus mengimpor kebutuhan minyak bumi untuk memenuhi kebutuhan dalam negeri.

Ekspor minyak bumi yang masih diperlukan untuk memenuhi kebutuhan dalam negeri jelas tidak sejalan dengan Pasal 33 ayat 3 Undang-Undang Dasar 1945 (UUD 1945) yang menyatakan bahwa bumi dan air dan kekayaan alam yang terkandung didalamnya dikuasai oleh negara dan dipergunakan untuk sebesar-besar kemakmuran rakyat. Permasalahan tersebut diatas tentunya terkait dengan aturan penyelenggaraan kegiatan usaha hulu minyak bumi Indonesia yang meliputi penyelenggaraan kegiatan usaha eksplorasi, eksploitasi, kegiatan pengolahan lapangan, pengangkutan, penyimpanan dan penjualan hasil produksi sendiri sebagai kelanjutan dari eksplorasi dan eksploitasi. Hal ini berarti bahwa aturan kegiatan usaha hulu juga mencakup aturan mengenai pendistribusian minyak bumi yang sangat penting dan berpengaruh dalam pengalokasian, penggunaan dan pemanfaatan minyak bumi nasional yang dibutuhkan di dalam negeri.

Pengaturan yang diterapkan sehubungan dengan pemenuhan energi dalam negeri dari minyak bumi nasional tersebut tentunya tidak terlepas dari aturan mengenai pembatasan ekspor minyak bumi yang dapat berupa pengenaan pajak atau bea ekspor (tarif), pembatasan jumlah minyak bumi yang diekspor, ijin ekspor minyak bumi dan kebijakan non-tarif lainnya yang dapat menghambat atau membatasi ekspor minyak bumi. ${ }^{2}$

Pembatasan minyak bumi untuk mengatasi krisis minyak mentah di Indonesia diatur oleh Undang-Undang Nomor 22 Tahun 2001 tentang Minyak dan Gas Bumi juga membatasi ekspor

${ }^{1}$ Fuel Production, Import and Domestic Sales, Indonesia Energy Statistic 2010, Ministry of Energy and Mineral Resources, hlm. 6

${ }^{2}$ Lode Van Den Hende and Jennifer Peterson, "Export Restriction on Raw Material WTO Rules and remedies,"Bloomberg Law Report (2009), hlm. 1. 
jumlah minyak bumi yang diekspor yang diatur dalam Pasal 22 ayat (1) yang menyebutkan Badan Usaha atau Bentuk Usaha Tetap wajib menyerahkan paling banyak 25\% (dua puluh lima persen) bagiannya dari hasil produksi Minyak Bumi dan/atau Gas Bumi untuk memenuhi kebutuhan dalam negeri. Bentuk Usaha Tetap dalam Pasal 1 ayat (18) menyebutkan bahwa sebagai badan usaha yang didirikan dan berbadan hukum di luar wilayah Negara Kesatuan Republik Indonesia yang melakukan kegiatan di wilayah Negara Kesatuan Republik Indonesia dan wajib mematuhi peraturan perundang-undangan yang berlaku di Republik Indonesia. Badan Usaha Tetap merupakan perusahaan transnasional yang harus tunduk pada peraturan Indonesia sebagaimana yang disebutkan dalam Undang-undang Nomor 22 Tahun 2001 tentang Minyak dan Gas Bumi.

Kontrak bagi hasil yang standar sesuai dengan Pasal 22 ayat (1) tentang Undang-Undang tentang Minyak dan Gas menyatakan bahwa Kontraktor harus menyerahkan minyak bumi yang diproduksi kepada pemerintah untuk memenuhi kebutuhan dalam negeri sebesar 25\% dari minyak bumi bagian kontraktor (Domestik Market Obligation (DMO)). DMO yang dimiliki kontraktor sesudah 60 bulan produksi akan dibeli dengan harga yang murah. Pembagian 25\% ini belum termasuk pajak atau contractor share (CS). Sebagai contoh pembagian di atas hak produksi kontraktor $44 \%$ dan untuk pemerintah 56\% sudah dihitung dengan pembagian $25 \%$ untuk pemerintah dan pemotongan pajak. ${ }^{3}$ Akibat dari pengaturan ini investor tidak mendapatkan dukungan untuk kepentingan investor agar memperoleh keuntungan yang maksimal.

Indonesia sebagai suatu negara mempunyai kewenangan untuk mengatur aturan dan kebijakan ekspor minyak bumi dalam rangka mengamankan kebutuhan energi dalam negerinya. Kewenangan tersebut tidak dapat sepenuhnya dilaksanakan di era globalisasi ekonomi ${ }^{4}$ atau perdagangan bebas antar negara saat ini apabila aturan dan kebijakan ekspor tersebut tidak sejalan atau bertentangan dengan ketentuan the World Trade Organization (WTO), yang telah diratifikasi oleh Indonesia melalui Undang-Undang nomor 7 tahun 1994 tentang Pengesahan Agreement Establishing the WTO (Perjanjian Pembentukan Organisasi Perdagangan Dunia). WTO Agreement tersebut mewajibkan setiap negara anggota terikat dan menerapkan Ketentuan WTO dalam peraturan perundangundangan nasional. ${ }^{5}$

WTO mengatur dalam Pasal XX huruf b dan $\mathrm{g}$ yang merupakan pengecualian inkosisten dengan GATT/WTO yang salah satu perlindungannya mengenai sumber daya alam. Pasal ini tidak diterapkan secara diskriminasi dan melakukan pembatasan yang terselubung terhadap perdagangan internasional.Penerapan pasal ini harus tunduk terhadap persyaratan dan langkah-langkah yang harus dipenuhi.Tindakan yang diambil suatu negara harus memenuhi syarat dan langkah-langkah dalam pengecualian GATT/WTO agar negara tersebut tidak dapat dikatakan melanggar ketentuan GATT/WTO.

DMO merupakan salah satu kebijakan pemerintah sebagai langkah pengecualian inkonsisten dengan GATT/ WTO yang memberikan perlindungan terhadap sumber daya alam.Tindakan pemerintah melalui DMO ini tidak memenuhi syarat pengecualian inkonsisten GATT/WTO. Pembatasan ekspor minyak dengan metode DMO menghambat perdagangan bebas yang melanggar ketentuan GAT'T/WTO

DMO (Domestic Market Obligation) yang diterapkan Indonesia semata-mata untuk membatasi Ekspor minyak yang dilakukan perusahaan transnasional dan mencukupi kebutuhan minyak bumi dalam negeri.DMO yang diberlakukan Indonesia merupakan sistem pembelian minyak yang dilakukan pemerintah dengan harga dibawah dari harga minyak dunia yang dijual oleh investor

\footnotetext{
${ }^{3}$ Adrian, Hukum Pertambangan, cetakan ke-2, Sinar Grafindo, Jakarta, 2012, hlm. 99

4Peter Van den Bossche, The Law and Policy of The World Trade Organization, CambridgeUniversity Press, Cambridge, 2005, hlm. 3

${ }^{5}$ Bhuiyan, Sharif. National Law in WTO Law, Effectiveness and Good Governance in the World Trading System. New York: Cambridge University Press, 2007. hlm. 132
} 
asing. Tindakan tersebut mengakibatkan kerugian kepada investor asing terhadap diberlakukannya DMO yang ada dalam Undang-undang No. 22 Tahun 2001 tentang Minyak dan Gas Bumi.

Pembatasan ekspor minyak bumi dengan menerapkan DMO pada dasarnya dapat menghambat akses negara anggota WTO lain terhadap minyak bumi Indonesia atau menghambat perdagangan antara negara yang tidak sesuai dengan tujuan WTO. Pembatasan ekspor minyak bumi dengan menerapkan DMO, apabila tidak sesuai dengan ketentuan WTO yang tercantum dalam GATT akan menjadi hal yang dapat dipermasalahkan oleh negara anggota WTO lainnya yang dirugikan khususnya yang mengandalkan impor minyak bumi untuk mengamankan pasokan energi nasionalnya sesuai dengan sistem penyelesaian sengketa WTO (WTO dispute settlement system). ${ }^{6}$ Berdasarkan hal tersebut, maka tulisan ini akan membahas peranan hukum nasional Indonesia terhadap pembatasan ekspor Minyak mentah melanggar Ketentuan GATT

\section{PEMBAHASAN}

\section{Indonesia Melanggar Ketentuan GATT terkait Ekpor Minyak Mentah}

Ketentuan GATT yang harus diperhatikan terkait dengan pembatasan ekspor minyak bumi adalah ketentuan Pasal XI ayat 1 GATT yang melarang untuk melakukan pembatasan ekspor produk selain tariff adalahtindakan DMO yaitu tindakan non tariff. Tindakan DMO diatur dalam UU No. 22 tahun 2001 tentang minyak dan gas bumi dalam Pasal Pasal 22 ayat (1) menyatakan bahwa Kontraktor harus menyerahkan minyak bumi yang diproduksi kepada pemerintah untuk memenuhi kebutuhan dalam negeri sebesar 25\% dari minyak bumi bagian kontraktor (Domestik Market Obligation (DMO)). DMO yang dimiliki kontraktor sesudah 60 bulan produksi akan dibeli dengan harga yang murah. Pembagian 25\% ini belum termasuk pajak atau contractor share (CS).

Pengecualian di bawah Pasal XX (b) dan (g) diaplikasikan ketika pelanggaran atas beberapa ketentuan dalam GATT

Pasal XX (b) dan (g) berbunyi bahwa:

"Subject to the requirement that such measures are not applied in a manner which would constitue a means of arbitrary or unjustifiable discrimination between countries where the same conditions prevail, or a disguised restriction on international trade, nothing in this agreement shall be construed to prevent the adoption or enforcement by any member of measures:

(b) necessary to protect human, animal or plant life or health

(g) relating to the conservation of exhaustible natural resources if such measures are made effective in conjuction with restrictions on domestic production;"

Pasal tersebut menyatakan bahwa setiap tindakan yang diambil yang inkonsisten dengan ketentuan GATT/W'TO tunduk pada persyaratan yang ada dan langkah-langkah tersebut tidak diterapkan secara diskriminasi di antara negara-negara pada saat berlaku kondisi yang sama atau adanya pembatasan terselubung terhadap perdagangan internasional.

Chapeau merupakan bagian dari Pasal XX yang tidak dapat dipisahkan.Maksud dan tujuan Chapeau Pasal XX adalah untuk menghindari kemungkinan penyalahgunaan atau penyimpangan penerapan kebijakan atas pengecualian sebagaimana diatur dalam Pasal XX.Chapean Pasal XX untuk memastikan keseimbangan antara hak anggota untuk memberlakukan pengecualian dalam Pasal XX dan kewajiban anggota tersebut untuk menghormati hak negara anggota lainnya dalam GATT. ${ }^{7}$ Keseimbangan tersebut dengan menetapkan persyaratan bahwa tindakan tersebut bukan merupakan (i) diskriminasi yang semena-mena atau tidak dapat dibenarkan diantara negara-negara anggota W'TO pada kondisi yang sama (arbitrary or unjustifiable discrimination between countries where the

\footnotetext{
${ }^{6}$ A WTO Secretariat Publication, A handbook on the WTO Dispute Settlement System, World Trade Organization (New York: Cambridge University Press, 2004), hlm. 2.

${ }^{7}$ Peter Van den Bossche, Op. cit. hlm. 616
} 
same conditions prevail) ${ }^{8}$ dan (ii) pembatasan tersamar atas perdagangan internasional (disguised restriction on international trade. . $^{9}$

Pengertian diskriminasi yang tidak dapat dibenarkan atau semena-mena (arbitrary or unjustifiable discrimination between countries where the same conditions prevaid) dalam pengertian Chapeau Pasal ${ }^{10} \mathrm{XX}$ (i) penerapan aturan atau kebijakan menimbulkan diskriminasi, (ii) diskriminasi tidak dapat dibenarkan atau semena-mena secara karakter dan (iii) diskriminasi terjadi diantara negara-negara pada saat kondisi yang sama berlaku. Pengertian pembatasan tersamar atas perdagangan internasional (disguised restriction on international trade) adalah apabila measure diterapkan/ untuk menyamarkan tujuan sebenarnya yaitu untuk membatasi perdagangan yang bertentangan dengan ketentuan atau kewajiban dalam GATT. Perlu mempertimbangkan pembuatan, penyusunan dan pengungkapan measure untuk menentukan maksud di balik penerapan measure.

DMO dapat diterapkan Indonesia dalam pengecualian pasal XX (g) GAT'T karena memenuhi ketentuan conservation natural resources Penelitian ini membahas bahwa pembatasan ekspor minyak bumi melanggar Pasal XI ayat 1 GAT'T. Berdasarkan Pasal XXIII GATT, pelanggaran atas ketentuan tersebut dapat memberikan hak kepada negara anggota WTO lain untuk mempersengketakan Indonesia sesuai Understanding on Rules and procedures Governing the Settlement of Dispute (DSU). Sistem dan Ketentuan WTO/GATT yang harus dipatuhi oleh anggota WTO secara menyeluruh (integral) tidak berarti bahwa sistem dan Ketentuan WTO/GATT terisolasi (clinically isolated) dari ketentuan hukum internasional lainnya karena ketentuan WTO/GATT merupakan bagian dari hukum internasional yang tidak tertutup (self-contained regimes). ${ }^{11}$ Oleh karenanya Ketentuan W'TO/GATT diinterpretasikan secara harmonis dengan prinsip hukum internasional, hukum kebiasaan internasional dan ketentuan hukum internasional lainnya yang berlaku sesuai dengan Pasal 31 (3) (c) Vienna Convention dan Pasal 3 ayat 2 DSU.

Analisis dari penelitian bab VI ini bahwa pembatasan ekspor minyak bumi terhadap kedaulatan ekonomi Indonesia adalah Indonesia dalam Pasal 25 dalam UU No. 22 Tahun 2001 tentang minyak dan gas bumi mengenai pembatasan minyak bumi melalui metode DMO dapat menerapkan Pasal pengecualian XX (g) GATT yang mengatur tentang natural resources. Pasal ini mensyaratkan adanya tujuan utama (Primarly aimed at) terhadap konservasi minyak bumi. UU No. 22 Tahun 2001 tentang Minyak dan gas bumi. UU No. 22 Tahun 2001 tentang Minyak dan gas bumi memiliki pengaturan konservasi sumber daya alam yang terdapat dalam Pasal 20 dan Pasal 42 menyatakan bahwa pengawasan yang dilakukan terhadap konservasi sumber daya alam dan cadangan minyak dan gas bumi tidak melanggar ketentuan GATT dan sudah sesuai dengan persyaratan pengecualian Pasal XX (g) GATT.

UU No. 22 Tahun 2001 tentang minyak dan gas bumi dalam Pasal 2 tidak memiliki tujuan utama untuk konservasi minyak bumi. Tujuan konservasi sumber daya alam yang tidak ada dalam Pasal 2 tidak menjadi masalah karena ada pengaturan konservasi sumber daya alam dalam Pasal 20 dan Pasal 42 yang dapat memenuhi syarat dalam Pasal XX (g) GATT. Tindakan DMO tidak mengakibatkan harus adanya perubahan karena tidak melanggar ketentuan GATT dan sudah sesuai dengan UU No. 22 Tahun tentang minyak dan gas bumi. Tindakan DMO yang dianggap dapat melanggar akan memiliki implikasi pembatasan minyak bumi terhadap kedaulatan ekonomi apabila UU No. 22 Tahun 2001 tentang minyak dan gas bumi tidak sesuai dengan ketentuan GATT.

\section{PENUTUP}

Indonesia menerapkan pembatasan ekspor Minyak bumi dengan domestic market obligation tidak melanggar ketentuan Pasal XI GATT yang sudah sesuai dengan pengecualian Pasal

${ }^{8}$ Koul, Autar Krishen, Guide to the WTO and GATT, USA: Kluwer Law International, 2005 hlm. 312

${ }^{9}$ Peter Van den Bossche, Op. cit., hlm. 617

10 Ibid

${ }^{11}$ Josst Pauwelyn, "The Role of Public International Law in the WTO: How Far Can we Go?"Journal., hlm. 26 
XX (g) GATT yaitu memiliki tujuan utama konservasi sumber daya alam. Pemerintah melakukan pembatasan dalam bentuk non tariff dengan cara menerapkan DMO yang merupakan wujud dari kedaulatan ekonomi Indonesia. Pembatasan ekspor minyak bumi yang diatur dalam UU No. 22 Tahun 2001 Tentang Minyak dan Gas bumi tidak memiliki implikasi terhadap kedaulatan ekonomi Indonesia. Indonesia sudah melaksanakan kewenangannya dan tidak melanggar ketentuan GATT/WTO

\section{REFERENCES}

A WTO Secretariat Publication, $A$ handbook on the WTO Dispute Settlement System, World Trade Organization (New York: Cambridge University Press, 2004)

Adrian, Hukum Pertambangan, cetakan ke-2, Sinar Grafindo, Jakarta, 2012

Adolf, Huala, Hukum Ekonomi Internasional, Bandung: CV Keni Media, 2010.

Amiruddin dan Zainal Asikin, Pengantar Penelitian Hukum, cetakan ke-3, Raja Grafindo, Jakarta, 2005

Andesgur, Ivnaini, Analisa Kebijakan Hukum Lingkungan dalam Pengelolaan Pestisida, Jurnal Bestuur Vol.VII, Issue.2, December, 2019.

Bethlehem Daniel, et. all. International Trade Law, first published (New York: Oxford University Press, 2009),

Bhuiyan Sharif,National Law in WTO Law, Effectiveness and Good Governance in the World Trading System. New York: Cambridge University Press, 2007.

Bossche, Peter Van den,The Law and Policy of The World Trade Organization, Cambridge University Press, Cambridge, 2005

Bossche Peter Van den, The law and Policy of the World Trade Organization, Text Cases and Materials (United Kingdom: Cambridge University Press), 2005.

Chintami Dian Balenina, Partisipasi Masyarakat dalam Pengelolaan Desa Sampah Mandiri di Desa Kalisoro, Tawangmangu, Kabupaten Karanganyar, Jurnal Bestuur Vol.VII, Issue.1, Agustus, 2019.

Endah Susanti, Liana, Economic Law Creation Beautiful Global Indonesia, Jurnal Bestuur Vol.VII, Issue.1, Agustus, 2019.

Estikomah, Solikah Ana, Aspek Hukum Import Sampah Plastik, Jurnal Bestuur Vol.VII, Issue.2, December, 2019.

F. Jonson Michael dan Jhon C. Keyser, Non Tariff Measures on Goods Trade in the East African Community,For The World Bank Proverty Reduction and Economic Management Africa Region, Washington DC

Handayani, I Gusti Ayu Ketut Rachmi, Lego Karjoko, dan Abdul Kadir Jaelani, Model Pelaksanaan Putusan Mahkamah Konstitusi yang Eksekutabilitas Dalam Pengujian Peraturan PerundangUndangan di Indonesia, Jurnal Bestuur Vol.VII, Issue.1, Agustus, 2019.

Muryani, Eni, Sinergisitas Penegakan Hukum Pada Kasus Pertambangan Emas Tanpa Izin di Kabupaten Banyumas, Jawa Tengah, Jurnal Bestuur Vol.VII, Issue.2, December, 2019.

Saputra, Rian, Adi Sulistiyono dan Emmy Latifah, Pendaftaran Internasional Sebagai Upaya Perlindungan Indikasi Geografis Indonesia Dalam Perdagangan Global (Study Peraturan Pemerintah Nomor 22 Tahun 2018), Jurnal IUS Kajian Hukum dan Keadilan Vol VII, No. 2 Agustus 2019.

Steve Charnobitz, "Exploring The Environtmental Exception in GATT Article XX", Journal of World Trade, 1991

Shih Wen-Chen, "Energy Security, GATT/WTO, and Regional Agreement," Natural Resources Journal, 2009.

Sunandar PS-PME Indonesia, "Tingkatkan Migas Nasional, Perlu Sinergitas Antar Instansi”, 6 April 2011, http://www.pmeindonesia.com/news/?catid=5\&newsId=3507, 
"Ketahanan Energi Mengkhawatirkan,” Media Indonesia.com, 4 Maret 2011, www.mediaindonesia.com/read/2011/03/04/207686/70/13/Ketahanan-Energi-

Mengkhawatirkan

"Satuan Kerja Khusus Pelaksana Kegiatan Usaha Hulu Minyak dan Gas Bumi", http://www.skkmigas.go.id/tentang-kami/profil,

https://www.wto.org/english/res_e/booksp_e/gatt_ai_e/preamble_e.pdf

http://www.skkmigas.go.id/tentang-kami/profil 